\title{
Pensamento Conservador Brasileiro: Características, especificidades e desenvolvimento
}

\author{
Leandro Rodrigues dos Santos
}

\begin{abstract}
Resumo
O objetivo deste trabalho é, inicialmente, mapear e compreender as principais características do pensamento político conservador desenvolvido no Brasil. Buscamos investigar suas especificidades em relação ao pensamento conservador anglo-saxônico, suas principais hipóteses acerca da formação social brasileira e os postulados que desenvolveram sobre a relação entre sociedade e Estado. Em um segundo momento, buscamos estudar dois intelectuais fundamentais neste processo: Oliveira Vianna e Gilberto Freyre. A partir da leitura de suas obras clássicas, Populações Meridionais do Brasil, no caso do primeiro e Casa Grande e Senzala, no caso do segundo, buscamos entender como os autores abordaram a formação social brasileira e o papel do Estado neste processo.
\end{abstract}

\section{Palavras-chave: Conservadorismo, Oliveira Vianna e Gilberto Freyre.}

\section{Introdução}

A formação de um pensamento político conservador no Brasil remete ao século XIX, quando se consolidou esta corrente de pensamento, sobretudo após o chamado "golpe da maioridade" e a consolidação do regime imperial. Algumas bases do pensamento conservador brasileiro são formuladas neste período, dentre elas, cita Gildo Marçal Brandão (2005): A educação das elites, o bloqueio da luta de classes, o enaltecimento da ordem em detrimento da liberdade, a limitação dos poderes regionais, a organização da população por meio de corporações e a direção e tutela da sociedade mediante a ação racional de um Estado Centralizado.

Oliveira Vianna, a partir da análise da formação social brasileira nos seus primeiros quatro séculos, constata uma sociedade dispersa e atomizada, cujos vínculos de integração e solidariedade são bastante frágeis e limitados, sendo o núcleo dos proprietários rurais o único estrato social capaz de hegemonizar-se e constituir em torno de si um considerável protagonismo político e a direção da sociedade. Diante da ausência de uma "hierarquia social organizada" (Vianna, 2005), o autor propõe um substancial aumento no papel de coordenação do Estado, algo que se contrapõe aos modos liberais de organização, ou seja, a democracia parlamentar e o sistema representativo.

Gilberto Freyre, em consonância com Oliveira Vianna, também nota a centralidade da iniciativa particular na formação social brasileira e seu protagonismo político e econômico. Mas, no autor pernambucano, essa questão não é um problema que precisa ser consertado pela ação estatal, é apenas um traço fundamental de nossa organização social pautada no que o autor chama de "equilíbrio de antagonismos" (Freyre, Gilberto. 2003). Esse equilíbrio relaciona-se com a influência africana na cultura dos nossos colonizadores portugueses, que, aqui, acabaram forjando uma sociedade que consegue, de forma exitosa, ensejar uma convivência razoavelmente harmônica entre elementos contrários. $O$ símbolo mais ostensivo desse equilíbrio é a modalidade de convivência aqui desenvolvida entre o senhor e o escravo.

\section{Resultados e Discussão}

Essa pesquisa é um passo inicial na compreensão do pensamento conservador no Brasil e logrou constituir uma elaboração, ainda que sumária, acerca das características do pensamento conservador no Brasil e seu desenvolvimento no campo disciplinar vinculado ao pensamento político. Conseguimos também sumarizar as diferentes contribuições de Oliveira Vianna e Gilberto Freyre sobre a formação social brasileira expostas em suas principais e seminais obras.

\section{Conclusões}

Concluímos que o estudo das bases do pensamento conservador no Brasil e de seus principais autores é de vital importância para a compreensão das características e particularidades do desenvolvimento social brasileiro e de sua modernização política e econômica. A questão mais importante que permeia a obra dos autores que aqui trabalhamos é a percepção que o Brasil é um país singular e, por diversos aspectos, distinto das sociedades anglo-saxãs. É importante frisar que, desde Burke, a avaliação da experiência histórica concreta é fundamental para a produção das ideias conservadoras. Portanto, a própria história brasileira logra engendrar postulados no pensamento conservador aqui desenvolvido que 0 fazem distinto do conservadorismo nascente nos países centrais.

\section{Agradecimentos}

Agradeço ao CNPq pelo financiamento desta pesquisa e pela oportunidade de participar deste congresso de iniciação científica. Meu agradecimento também ao Professor Alvaro Bianchi por ter aceitado orientar este projeto e a todos os componentes do grupo de estudos sobre pensamento conservador desenvolvido no âmbito do PEPOL (Laboratório de Pensamento Político). As discussões que ali desenvolvemos foram fundamentais tanto para a minha formação intelectual quanto para o desenvolvimento deste trabalho.

BRANDÃO, Gildo Marçal. "Linhagens do Pensamento Político Brasileiro". DADOS - Revista de Ciências Sociais, Rio de Janeiro, Vol. 48, no 2, 2005, pp. 231 a 269. Disponível em:

http://www.scielo.br/pdf/dados/v48n2/a01v48n2.pdf

FREYRE, Gilberto. "Casa Grande \& Senzala. Formação da família brasileira sob o regime da economia patriarcal"/ Gilberto Freyre; apresentação de Fernando Henrique Cardoso - 48 ${ }^{\circ}$ ed. rev. - São Paulo: Global, 2003(Introdução à história da sociedade patriarcal no Brasil; 1).

OLIVEIRA VIANNA, F. J. Populações Meridionais do Brasil. Brasília Senado Federal, Conselho Editorial, 2005. 424 p. -- (Edições do Senado Federal ; v. 27)

NISBET, Robert. O conservadorismo. Lisboa, Estampa, 1987. 